\title{
Evaluation of Daylight Intensity for Sustainbility in Residential Buildings in Cantonment Cottages Multan
}

\author{
SUMRA YOUSUF*, SABAHAT ALAMGIR**, MUHAMMAD AFZAL***, SOHAIL MAQSOOD****, \\ AND MUHAMMAD SALAAR ARIF***** \\ RECEIVED ON 14.03.2016 ACCEPTED ON 22.11.2016
}

\begin{abstract}
Day lighting is a useful and effective source of energy savings and visual comforts in buildings. Occupants expect good daylight in their living spaces for better living environment. The quality and quantity of natural light entering in to a building depend on both internal and external factors. Daylight strategies basically depend on the accessibility of natural light that is determined by the latitude of the building site and the conditions surrounding the building. Daylight provides lighting energy and energy demand reduction during peak utility hours. Bringing daylight into a building that displaces electric lighting and provides sufficient illumination is the greenest way to light a building presently. This research, aims at analyzing the daylight intensity in residential buildings in Cantonment Cottages Multan which is one of the hottest and progresse city of Pakistan. The intensity of daylight can be expressed in the terms of luminance and daylight factor. In this research, the 5 and 7 marla houses in Cantt Cottages in Multan were selected. The device lux meter was used for measuring intensity with which the brightness appears to the human eye. The readings were taken by placing Lux Meter at the center and near windows in each building component at $2-4 \mathrm{pm}$. Inorderto evaluate the daylight intensity, the measured luminance in each component of building is compared with the standard illuminance as per recommendation of CIBSE (Chartered Institute of Building Service Engineers). After investigation, it has been found that daylight factor is much higher than the standard values in east and west oriented building components whereas the building components oriented in north and south, the day light factor is little higher than standard values as per recommended by CIBSE. The design parameters including building orientation, glazing area, room size to window opening ratio etc. is not appropriate with respect to sustainable design.
\end{abstract}

Key Words: Daylight Intensity, Lux Meter, Day Light Factor, Standard Luminance, Chartered Institute of Building Service Engineers, Cantonment Cottages Multan.

\section{INTRODUCTION}


the electrical energy was provided as supplementary source of light. After which, the daylight had become out of fashion due to the availability of economical electricity. But the depletion of energy resources and the environmental effects led the designer to reuse daylighting strategies in buildings in-order-to minimize the energy use for lighting and air conditioning and electrical fixtures [1-2].

Day lighting is controlled entrance of natural light (direct sunlight and diffuse skylight) into the buildings for the reduction of electric lights and energy saving. Daylighting creates visually productive environment for building users by minimizing about one-third of total building energy costs. A day-lighting system typically consists of skylights windows, and daylight control system.

The basic cause for using daylight is to fulfill the illumination requirements of an architectural design and maximum possible energy saving. Good day lighting design improves the overall feelings, satisfaction, and comfort level of building users. Different research studies show that proper day lighting design in different building types and functions increase worker productivity and reduce absenteeism in office buildings, improve student educational performance in schools, and improve patient recovery times in hospitals. Daylight also improves common health of building inmates. In short, introducing controlled daylight into buildings improve its overall energy efficiency.

In this research, the residential buildings of Cantt Cottages (Housing Society) were investigated to to either daylight entering to the designated houses is sufficient or not. For this purpose, the luminance and daylight factor of 5 and 7 Marla houses were find out and compared with standard luminance levels of as per recommendations of CIBSE.

\section{LITERATURE REVIEW}

With the passage of time, more attention is being taken towards the study of natural lighting in buildings. Much research has been carried out for the last few decades. The availability of natural light varies across the world, which is determined by the latitude of the building locations and the conditions immediately surrounding the proposed building, e.g., the presence of obstructions [2-3]. The entrance of daylight in buildings decreases the cost of energy up-to many extents. It has been analyzed by Capeluto [5] that in a well-designed building, daylight reduces energy costs, improves visual quality, and provides psychological benefits that are very tough and expensive to produce with electrical lighting [3]. Not only the cost but daylight also have positive impacts on human health. According to Youssef [6] insufficient daylight may cause many serious diseases like general weakness, the feeling of exhausting, and hypoxia, nephrology diseases, cardiac muscle weakness etc. [4]. Moreover, Rea [7] concluded many points regarding health of human being and light, one of them is natural light has a direct impact on cortical brain activity [5]. Natural light is an important aspect of green building design. The justification for what constitutes "good" vs "bad" daylight design in green building is measured via the Daylight factor [8]. The daylight factor describes the variation internal horizontal illuminance to the external horizontal illuminance of a building component.

\section{METHODOLOGY}

Relevant literature on standard procedure for analysis of daylighting in buildings was reviewed from different books, codes, standards, and relevant research publications. The Cottages (Multan) was taken as case study and its layout plan is shown Fig. 1, as the of Multan is one of the hottest cityof Pakistan where the daylight perception is comparatively higher. Since Multan is a

Mehran University Research Journal of Engineering \& Technology, Volume 36, No. 3, July, 2017 [p-ISSN: 0254-7821, e-ISSN: 2413-7219] 
progressive, developing and populated city where number of societies are being developed, therefore, it was necessary to carry out thorough investigation of daylight intensity in residential buildings in Multan and that could is a step foot toward green building design for the sustainable architectural design .

Digital thermometers were used to measure the temperature of all components of building (in each 5 and 7 Marla house ). All the temperatures were measured by placing digital thermometer at the center of each building component and then tabulated all the readings for both 5 and 7 the houses.

The Lux meter was used for measuring brightness and intensity with which the brightness appears to the human eye. The readings were taken by placing the Lux meter at the center and near windows in both building component at 2-4 pm. The readings were calculated for each component in 5 and 7 Marla houses and all the results were tabulated.

Daylight factor for each building component was calculated by the following formula:

$\mathrm{DF}=\left(\mathrm{E}_{\mathrm{i}} / \mathrm{E}_{\mathrm{o}}\right) \times 100$
Where $E_{i}$ is 1 illuminance due to day lighting at a point on the indoors working plane, $\mathrm{E}_{\mathrm{o}}$ is simultaneous out door illuminance on a horizontal plane from an unobstructed hemisphere of overcast sky:

$\mathrm{DF}=0.1 \times \mathrm{P}$

Where DF is Day light factor, P is Percentage of glazing to floor area.

\section{RESULTS AND DISCUSSION}

Complete data including the DF and glazing to floor areas was obtained for the analysis.

\subsection{Measurement of Temperature and Luminance and Comparison with Standard Values}

The reading thus taken from thermometer and daylight intensity for above designated case study for 5 and 7 Marla house for each floor is tabulated in Tables 1-2 and corresponding detailed plans are shown in Figs. 2-3 respectively.

After obtaining the data of temberatures and lux meter for each building component of above designated houses,

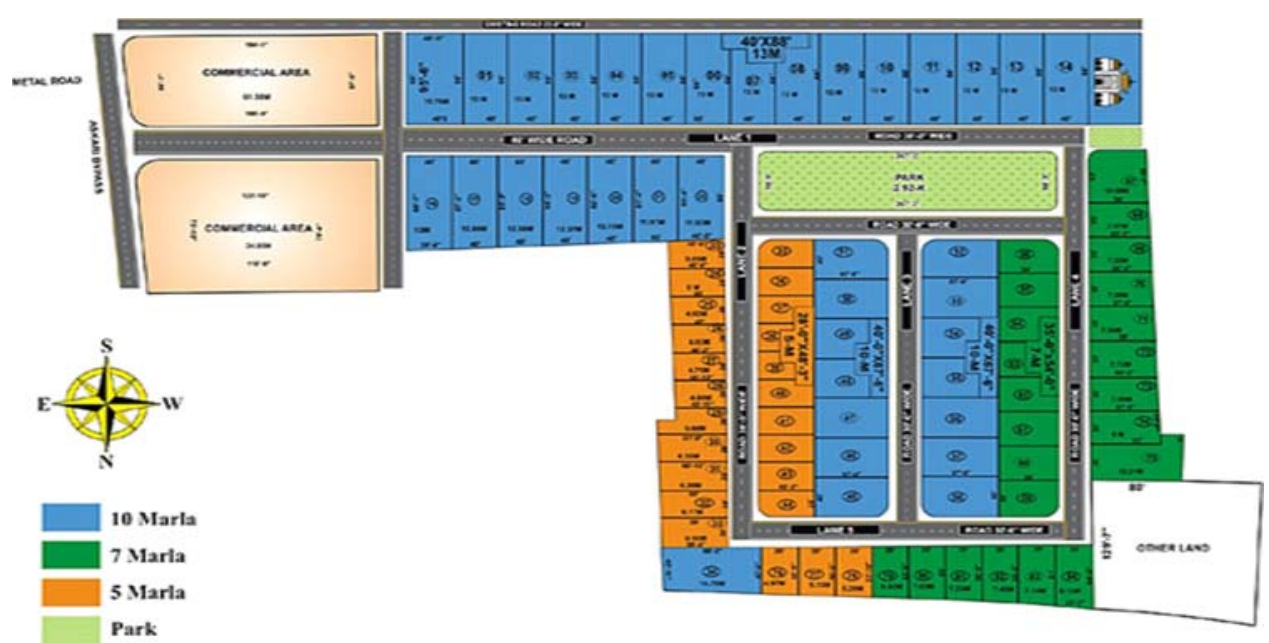

FIG. 1. LAYOUTPLAN OF CANTT COTTAGES

Mehran University Research Journal of Engineering \& Technology, Volume 36, No. 3, July, 2017 [p-ISSN: 0254-7821, e-ISSN: 2413-7219] 
the lux meter readings were compared with the standard

from CIBSE Code for Lighting Part-2 [9]. This comparison luminance. The standard luminance values were obtained has been shown in Tables 3-4.

TABLE 1. MEASURED TEMPERATURE AND DAYLIGHTINTENSITY FOR SELECTEDCASE STUDY 5 MARLA HOUSE

\begin{tabular}{|c|c|c|c|c|c|c|}
\hline \multirow{3}{*}{ No. } & \multirow{3}{*}{ Building Component } & \multirow{3}{*}{ Orientation } & \multicolumn{3}{|c|}{ Instrumental Readings } & \multirow{3}{*}{ Time } \\
\hline & & & \multirow{2}{*}{$\begin{array}{c}\text { Digital Thermometer } \\
\text { At Center (Ei) }\end{array}$} & \multicolumn{2}{|c|}{ Lux Meter } & \\
\hline & & & & At Center (Ei) & Near Window (Eo) & \\
\hline \multicolumn{7}{|c|}{ Ground Floor } \\
\hline 1. & Bed & East & $31.7^{\circ} \mathrm{C}$ & 985 & 2720 & \multirow{6}{*}{$2-4 \mathrm{pm}$} \\
\hline 2. & Bath & East & $31.6^{\circ} \mathrm{C}$ & 210 & 2720 & \\
\hline 3. & Lounge + Dining & East & $31.6^{\circ} \mathrm{C}$ & 705 & 1650 & \\
\hline 4. & Kitchen & West & $31.7^{\circ} \mathrm{C}$ & 580 & 1550 & \\
\hline 5. & Bed & West & $31.6^{\circ} \mathrm{C}$ & 750 & 2100 & \\
\hline 6. & Bath-West & $31.50 \mathrm{C}$ & 700 & 1600 & - & \\
\hline \multicolumn{7}{|c|}{ First Floor } \\
\hline 1. & Bed & East & $32.8^{\circ} \mathrm{C}$ & 670 & 3120 & \multirow{8}{*}{$2-4 \mathrm{pm}$} \\
\hline 2. & Bath & East & $32.6^{\circ} \mathrm{C}$ & 660 & 3100 & \\
\hline 3. & Veranda & East & $32.9^{\circ} \mathrm{C}$ & 259 & 2590 & \\
\hline 4. & Lounge & North & $31.7^{\circ} \mathrm{C}$ & 590 & 1700 & \\
\hline 5. & Store & South & $32.4^{\circ} \mathrm{C}$ & 150 & No window & \\
\hline 6. & Bed & West & $32.6^{\circ} \mathrm{C}$ & 750 & 1500 & \\
\hline 7. & Bed & West & $32.6^{\circ} \mathrm{C}$ & 750 & 1500 & \\
\hline 8. & Bath & West & $31.6^{\circ} \mathrm{C}$ & 165 & 1450 & \\
\hline
\end{tabular}

TABLE 2. MEASURED TEMPERATURE AND DAYLIGHT INTENSITY FOR SELECTED CASE STUDY 7 MARLA HOUSE

\begin{tabular}{|c|c|c|c|c|c|c|}
\hline \multirow{3}{*}{ No. } & \multirow{3}{*}{ Building Component } & \multirow{3}{*}{ Orientation } & \multicolumn{3}{|c|}{ Instrumental Readings } & \multirow{3}{*}{ Time } \\
\hline & & & \multirow{2}{*}{$\begin{array}{c}\text { Digital Thermometer } \\
\text { At Center (Ei) }\end{array}$} & \multicolumn{2}{|c|}{ Lux Meter } & \\
\hline & & & & At Center (Ei) & Near Window (Eo) & \\
\hline \multicolumn{7}{|c|}{ Ground Floor } \\
\hline 1. & Bed & South & $31.2^{\circ} \mathrm{C}$ & 894 & 1860 & \multirow{7}{*}{$2-4 \mathrm{pm}$} \\
\hline 2. & Bath & East & $30.9^{\circ} \mathrm{C}$ & 160 & 1510 & \\
\hline 3. & Lounge Dining & South & $31.6^{\circ} \mathrm{C}$ & 670 & 2730 & \\
\hline 4. & Kitchen & East & $31.9^{\circ} \mathrm{C}$ & 590 & 1550 & \\
\hline 5. & Drawing & West & $33.7^{\circ} \mathrm{C}$ & 348 & 2730 & \\
\hline 6. & Lobby & West & $31.8^{\circ} \mathrm{C}$ & 420 & 2700 & \\
\hline 7. & PWD & South & $33.6^{\circ} \mathrm{C}$ & 230 & 1490 & \\
\hline \multicolumn{7}{|c|}{ First Floor } \\
\hline 1. & Bed & West & $33.9 \mathrm{oC}$ & 670 & 2790 & \multirow{7}{*}{$2-4 \mathrm{pm}$} \\
\hline 2. & Bath & South & $33.60 \mathrm{C}$ & 250 & 1490 & \\
\hline 3. & Bed & South & $32.10 \mathrm{C}$ & 670 & 2730 & \\
\hline 4. & Bed & South & $31.20 \mathrm{C}$ & 894 & 1860 & \\
\hline 5. & Store & North & $31.0 \mathrm{oC}$ & 144 & No window & \\
\hline 6. & Bath & East & $30.9 \mathrm{oC}$ & 160 & 1510 & \\
\hline 7. & Bath & East & $31.9 \mathrm{oC}$ & 590 & 1550 & \\
\hline
\end{tabular}

Mehran University Research Journal of Engineering \& Technology, Volume 36, No. 3, July, 2017 [p-ISSN: 0254-7821, e-ISSN: 2413-7219] 


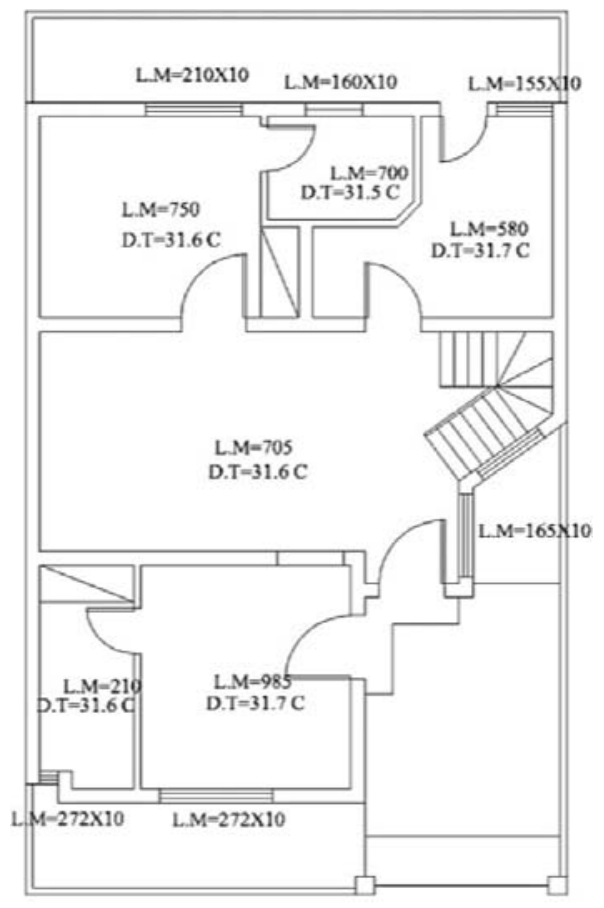

GROUND FLOOR

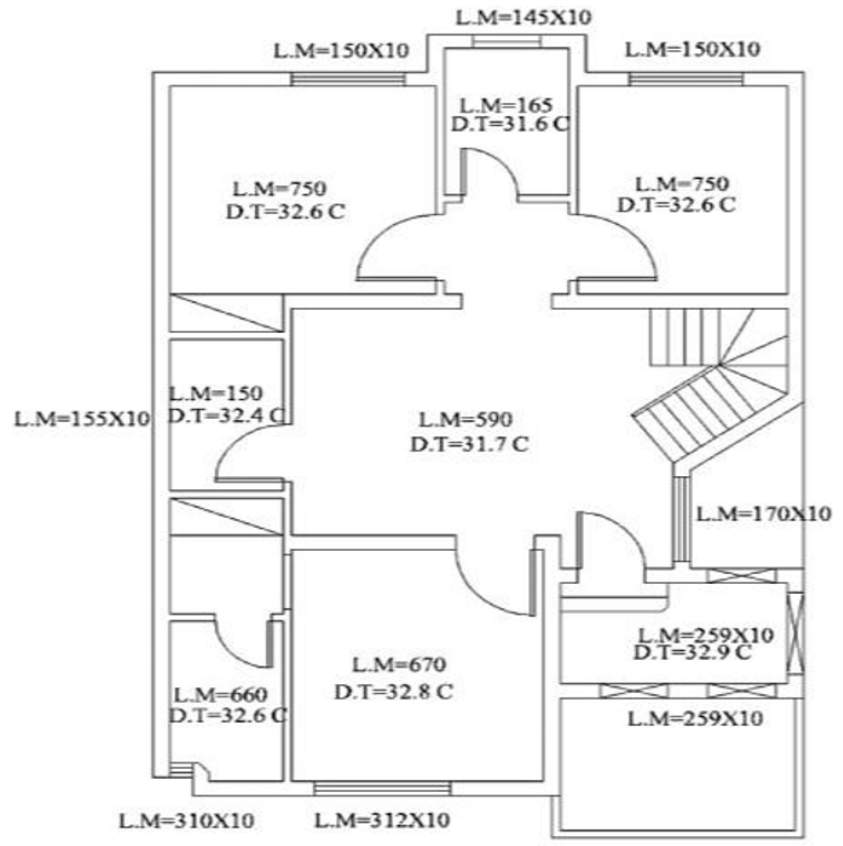

FIRST FLOOR

FIG. 2.DETAILED ARCHITECTURAL PLANS OF 5 MARLA HOUSE

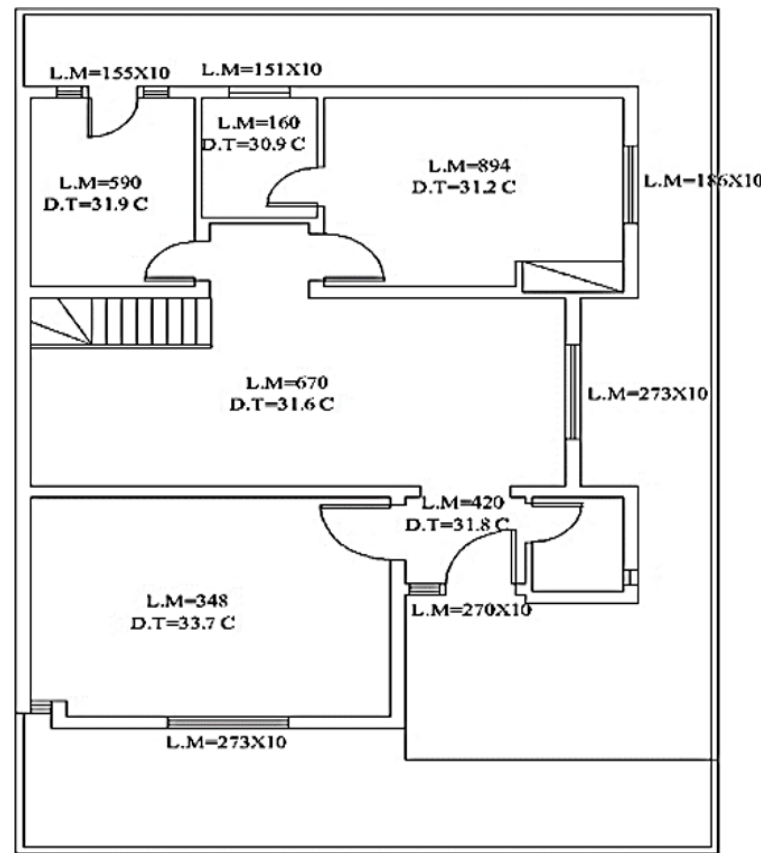

GROUND FLOUR

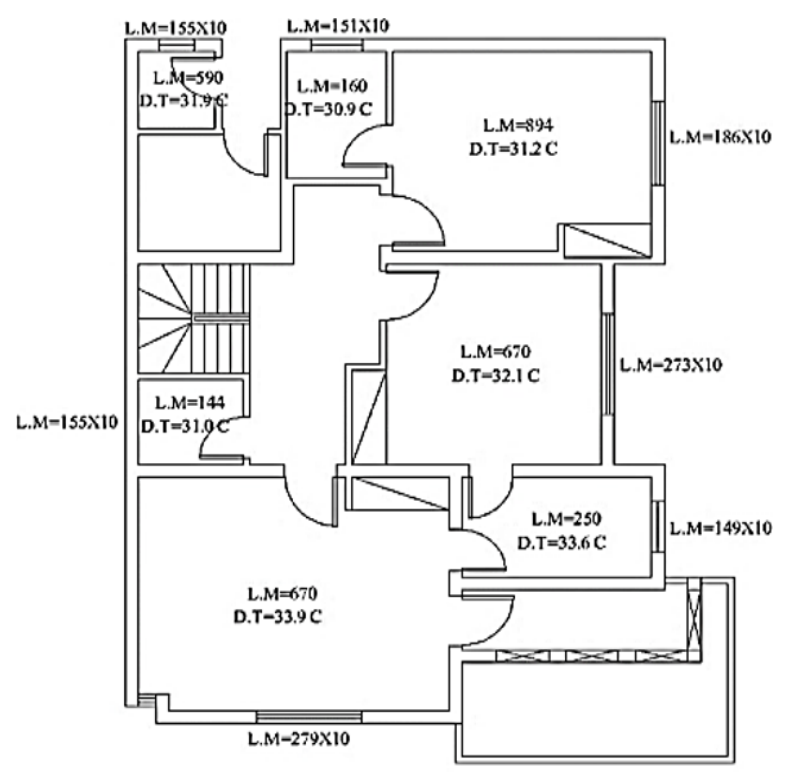

FIRST FLOXOR

FIG. 3. DETAILED ARCHITECTURAL PLANS OF 7 MARLA HOUSE

Mehran University Research Journal of Engineering \& Technology, Volume 36, No. 3, July, 2017 [p-ISSN: 0254-7821, e-ISSN: 2413-7219] 
Evaluation of Daylight Intensity for Sustainbility in Residential Buildings in Cantonment Cottages Multan

TABLE 3. COMPARISON OF MEASURED LUX METER READINGS WITH STANDARD LUX METER READINGS FOR 5 MARLA HOUSE

\begin{tabular}{|c|c|c|c|c|c|}
\hline No. & Building Component & Orientation & Glazing Area & $\begin{array}{l}\text { Measured Lux } \\
\text { Meter Readings } \\
\text { At Centre (Ei) }\end{array}$ & $\begin{array}{c}\text { Standard Lux } \\
\text { Meter Readings [4] }\end{array}$ \\
\hline \multicolumn{6}{|c|}{ Ground Floor } \\
\hline 1. & Bed & East & 48 & 985 & $300-400$ \\
\hline 2. & Bath & East & 4.5 & 210 & $250-300$ \\
\hline 3. & Lounge+ Dinning & East & 54 & 705 & $300-500$ \\
\hline 4. & Kitchen & West & 9 & 580 & 500 \\
\hline 5. & Bed & West & 48 & 750 & $300-400$ \\
\hline 6. & Bath & West & 9 & 700 & $250-300$ \\
\hline \multicolumn{6}{|c|}{ First Floor } \\
\hline 1. & Bed & East & 48 & 670 & $300-400$ \\
\hline 2. & Bath & East & 4.5 & 660 & $250-300$ \\
\hline 3. & Veranda & East & No Window & 259 & 500 \\
\hline 4. & Lounge & North & 30 & 590 & $300-500$ \\
\hline 5. & Store & South & No Window & 150 & 100 \\
\hline 6. & Bed & West & 48 & 750 & $300-400$ \\
\hline 7. & Bed & West & 48 & 750 & $300-400$ \\
\hline 8. & Bath & West & 9 & 165 & $250-300$ \\
\hline
\end{tabular}

TABLE 4. COMPARISON OF MEASURED LUX METER READINGS WITH STANDARD LUX METER READINGS FOR 7 MARLA HOUSE

\begin{tabular}{|c|c|c|c|c|c|}
\hline No. & Building Component & Orientation & Glazing Area & $\begin{array}{l}\text { Measured Lux } \\
\text { Meter Readings } \\
\text { At Centre (Ei) }\end{array}$ & $\begin{array}{c}\text { Standard Lux } \\
\text { Meter Readings [4] }\end{array}$ \\
\hline \multicolumn{6}{|c|}{ Ground Floor } \\
\hline 1. & Bed & South & 36 & 894 & $300-400$ \\
\hline 2. & Bath & East & 9 & 160 & $250-300$ \\
\hline 3. & Lounge+ Dinning & South & 48 & 670 & $300-500$ \\
\hline 4. & Kitchen & East & 36 & 590 & 500 \\
\hline 5. & Drawing & West & 54 & 348 & $300-400$ \\
\hline 6. & Lobby & West & 20 & 420 & 300 \\
\hline \multicolumn{6}{|c|}{ First Floor } \\
\hline 1. & Bed & West & 54 & 670 & $300-400$ \\
\hline 2. & Bath & South & 9 & 250 & $250-300$ \\
\hline 3. & Bed & South & 48 & 670 & $300-400$ \\
\hline 4. & Bed & South & 36 & 894 & $300-400$ \\
\hline 5. & Store & North & No Window & 144 & 100 \\
\hline 6. & Bath & East & 9 & 160 & $250-300$ \\
\hline 7. & Bath & East & 6 & 590 & $250-300$ \\
\hline 8. & Bed & West & 54 & 670 & $300-400$ \\
\hline
\end{tabular}

Mehran University Research Journal of Engineering \& Technology, Volume 36, No. 3, July, 2017 [p-ISSN: 0254-7821, e-ISSN: 2413-7219] 
Following conclusions can be drawn from the above results as mentioned below:

- $\quad$ Measured internal daylight intensity by Lux Meter for some building components is higher than standard values of daylight intensity because of larger sizes of window openings as compared to total floor areas of different building components. So, solar shades and fiber blinds should be used on all these window openings.

- $\quad$ In some of the components measured internal daylight intensity by Lux Meter is lower than standard values of daylight intensity because of smaller sizes of window openings as compared to total floor areas so ratio of window to floor area should be appropriate in these components.
- $\quad$ Measured internal Daylight intensity by Lux Meter for some building components is in the range as according to the standard values of daylight intensity so their architectural design is appropriate and according to the standards.

- $\quad$ Illuminance varies directly with the glazing area. Higher the glazing area higher will be illuminance.

\subsection{Calculation of Daylight Factor and Comparison with Standard Value for 5 and 7 Marla Houses}

The daylight factor for each component of designated houses were calculated by using Equation (2). The results thus obtained are tabulated in Tables 5-6 whereas the comparison with standard value is shown in Tables 7-8 respectively.

TABLE 5. CALCULATION OF DAYLIGHT FACTOR (FROM PERCENTAGE GLAZING AREA TO FLOOR AREA) FOR 5 MARLA HOUSE

\begin{tabular}{|c|c|c|c|c|c|c|}
\hline \multirow{2}{*}{ No. } & \multirow{2}{*}{ Building Component } & \multirow{2}{*}{ Orientation } & \multicolumn{2}{|c|}{ Area (Sq. Ft.) } & \multirow{2}{*}{$\begin{array}{c}\text { P (Percentage } \\
\text { Glazing Area to } \\
\text { Floor Area) }\end{array}$} & \multirow{2}{*}{$\mathrm{DF}=0.1 \mathrm{xP}$} \\
\hline & & & Glazing Area & Floor Area & & \\
\hline \multicolumn{7}{|c|}{ Ground Floor } \\
\hline 1. & Bed & East & 48 & 136.25 & 35.23 & 3.5 \\
\hline 2. & Bath & East & 4.5 & 61.25 & 7.35 & 0.7 \\
\hline 3. & Lounge + Dinning & East & 54 & 258 & 29.93 & 3.0 \\
\hline 4. & Kitchen & West & 9 & 77 & 11.69 & 1.2 \\
\hline 5. & Bed & West & 48 & 129.25 & 37.14 & 3.7 \\
\hline 6. & Bath & West & 9 & 43.5 & 20.69 & 2.1 \\
\hline \multicolumn{7}{|c|}{ First Floor } \\
\hline 1. & Bed & East & 48 & 134.75 & 35.62 & 3.6 \\
\hline 2. & Bath & East & 4.5 & 43.5 & 10.34 & 1.0 \\
\hline 3. & Lounge & North & 30 & 192 & 15.63 & 1.6 \\
\hline 4. & Bed & West & 48 & 129.25 & 37.14 & 3.7 \\
\hline 5. & Bed & West & 48 & 101.75 & 47.17 & 4.7 \\
\hline 6. & Bath & West & 9 & 42.5 & 21.18 & 2.1 \\
\hline
\end{tabular}

Mehran University Research Journal of Engineering \& Technology, Volume 36, No. 3, July, 2017 [p-ISSN: 0254-7821, e-ISSN: 2413-7219] 
Evaluation of Daylight Intensity for Sustainbility in Residential Buildings in Cantonment Cottages Multan

TABLE 6. CALCULATION OF DAYLIGHT FACTOR (FROM PERCENTAGE GLAZING AREA TO FLOOR AREA) FOR 7 MARLA HOUSE

\begin{tabular}{|c|c|c|c|c|c|c|}
\hline \multirow{2}{*}{ No. } & \multirow{2}{*}{ Building Component } & \multirow{2}{*}{ Orientation } & \multicolumn{2}{|c|}{ Area (Sq. Ft.) } & \multirow{2}{*}{$\begin{array}{l}\text { P (Percentage } \\
\text { Glazing Area to } \\
\text { Floor Area) }\end{array}$} & \multirow{2}{*}{$\mathrm{DF}=0.1 \mathrm{xP}$} \\
\hline & & & Glazing Area & Floor Area & & \\
\hline \multicolumn{7}{|c|}{ Ground Floor } \\
\hline 1. & Bed & South & 36 & 178 & 20.22 & 2.0 \\
\hline 2. & Bath & East & 9 & 44 & 20.45 & 2.0 \\
\hline 3. & Lounge + Dinning & South & 48 & 324 & 14.81 & 1.5 \\
\hline 4. & Kitchen & East & 36 & 102 & 35.29 & 3.5 \\
\hline 5. & Drawing & West & 54 & 255 & 21.18 & 2.1 \\
\hline 6. & Lobby & West & 20 & 33 & 60.60 & 6.1 \\
\hline 7. & PWD & South & 4.5 & 27 & 16.67 & 1.7 \\
\hline \multicolumn{7}{|c|}{ First Floor } \\
\hline 1. & Bed & West & 54 & 255 & 21.18 & 2.1 \\
\hline 2. & Bath & South & 9 & 65.25 & 13.79 & 1.4 \\
\hline 3. & Bed & South & 48 & 148.5 & 32.32 & 3.2 \\
\hline 4. & Bed & South & 36 & 178.5 & 20.17 & 2.0 \\
\hline 5. & Bath & East & 9 & 44 & 20.45 & 2.0 \\
\hline 6. & Bath & East & 6 & 20.25 & 29.63 & 3.0 \\
\hline
\end{tabular}

TABLE 7. COMPARISON BETWEEN CALCULATED DF AND STANDARD DF FOR 5 MARLA HOUSE

\begin{tabular}{|c|c|c|c|c|c|}
\hline No. & Building Component & Orientation & $\begin{array}{c}\text { P (Percentage } \\
\text { Glazing Area to } \\
\text { Floor Area) } \\
\end{array}$ & $\mathrm{DF}=0.1 \mathrm{xP}$ & Standard DF \\
\hline \multicolumn{6}{|c|}{ Ground Floor } \\
\hline 1. & Bed & East & 35.23 & 3.5 & 0.5 \\
\hline 2. & Bath & East & 7.35 & 0.7 & 1.5 \\
\hline 3. & Lounge + Dinning & East & 29.93 & 3.0 & 1.0 \\
\hline 4. & Kitchen & West & 11.69 & 1.2 & 2.0 \\
\hline 5. & Bed & West & 37.14 & 3.7 & 0.5 \\
\hline 6. & Bath & West & 20.69 & 2.1 & 1.5 \\
\hline \multicolumn{6}{|c|}{ First Floor } \\
\hline 1. & Bed & East & 35.62 & 3.6 & 0.5 \\
\hline 2. & Bath & East & 10.34 & 1.0 & 1.5 \\
\hline 3. & Lounge & North & 15.63 & 1.6 & 1.0 \\
\hline 4. & Bed & West & 37.14 & 3.7 & 0.5 \\
\hline 5. & Bed & West & 47.17 & 4.7 & 0.5 \\
\hline 6. & Bath & West & 21.18 & 2.1 & 1.5 \\
\hline
\end{tabular}

Mehran University Research Journal of Engineering \& Technology, Volume 36, No. 3, July, 2017 [p-ISSN: 0254-7821, e-ISSN: 2413-7219] 


\subsection{Graphical Representation}

Following is the graphical representation of comparison of calculated daylight factor with standard daylight factor values given in Figs. 4-7 for 5 and 7 marla houses.

The following points can be concluded from the

Figs. 4-7 as:

(a) Daylight factor is directly related to P (Percentage glazing to floor area). (b) The daylight factor for different building components is higher than standard values of daylight factor. It is because of the larger glazing areas as compared to total floor areas. In very few of the above cases calculated daylight factor for some of the building components is lower than standard values of daylight factor.

(c) For better architectural daylight design, $\mathrm{P}$ (Percentage glazing to floor area) should be according to the architectural lighting standards.

TABLE 8. COMPARISON BETWEEN CALCULATED DF AND STANDARD DF FOR 7 MARLA HOUSE

\begin{tabular}{|c|c|c|c|c|c|}
\hline No. & Building Component & Orientation & $\begin{array}{l}\text { P (Percentage } \\
\text { Glazing Area to } \\
\text { Floor Area) }\end{array}$ & $\mathrm{DF}=0.1 \mathrm{xP}$ & Standard DF \\
\hline \multicolumn{6}{|c|}{ Ground Floor } \\
\hline 1. & Bed & South & 20.22 & 2.0 & 0.5 \\
\hline 2. & Bath & East & 20.45 & 2.0 & 1.5 \\
\hline 3. & Lounge + Dinning & South & 14.81 & 1.5 & 1.0 \\
\hline 4. & Kitchen & East & 35.29 & 3.5 & 2.0 \\
\hline 5. & Drawing & West & 21.18 & 2.1 & 1.0 \\
\hline 6. & Lobby & West & 60.60 & 6.1 & 2.0 \\
\hline 7. & PWD & South & 16.67 & 1.7 & 1.5 \\
\hline \multicolumn{6}{|c|}{ First Floor } \\
\hline 1. & Bed & West & 21.18 & 2.1 & 0.5 \\
\hline 2. & Bath & South & 13.79 & 1.4 & 1.5 \\
\hline 3. & Bed & South & 32.32 & 3.2 & 0.5 \\
\hline 4. & Bed & South & 20.17 & 2.0 & 0.5 \\
\hline 5. & Bath & East & 20.45 & 2.0 & 1.5 \\
\hline 6. & Bath & East & 29.63 & 3.0 & 1.5 \\
\hline
\end{tabular}




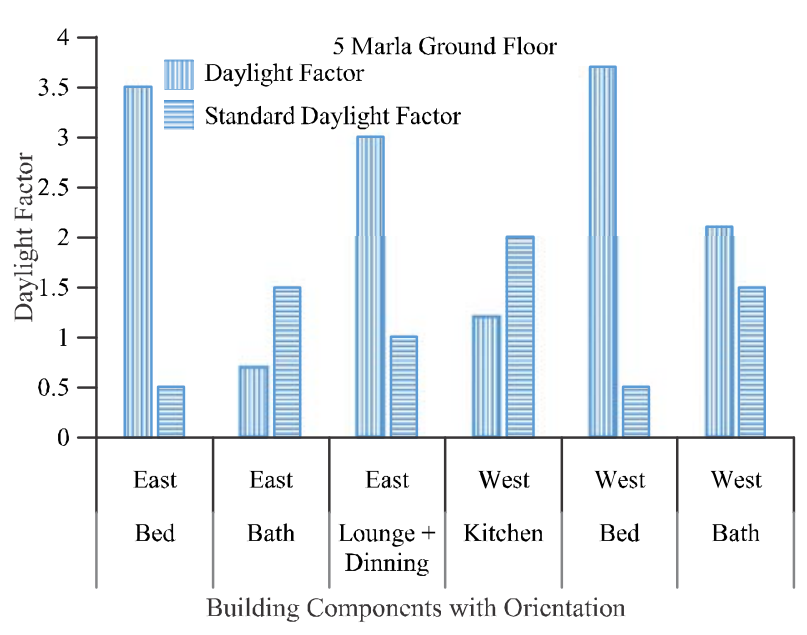

FIG. 4. COMPARISON BETWEEN DAYLIGHT FACTOR AND STANDARD DAYLIGHT FACTOR FOR GROUND FLOOR OF FIVE MARLA HOUSE

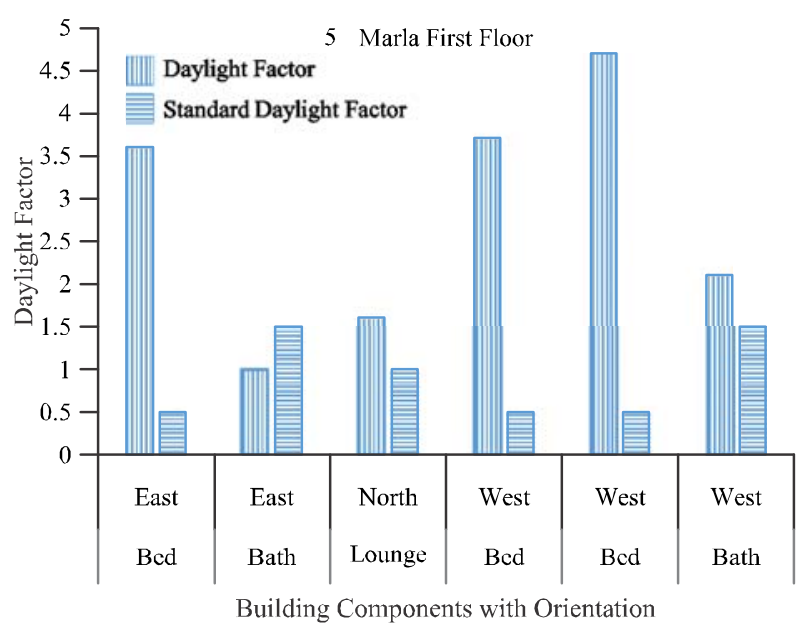

FIG. 5. COMPARISON BETWEEN DAYLIGHT FACTOR AND STANDARD DAYLIGHT FACTOR FOR FIRST FLOOR OF FIVE MARLA HOUSE

\section{CONCLUSIONS}

The following conclusions can be drawn from the analyzed results.

(i) The overall architectural design for both 5 and 7 marla house is melfunctioning regarding buidling orientation, glazing area, room size to window etc. This is because, most of the building components are receiving relatively higher

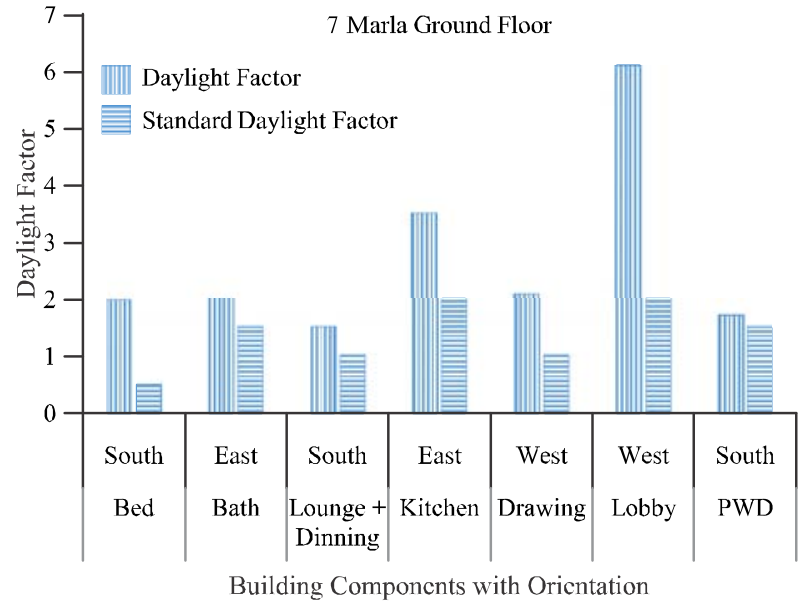

FIG. 6. COMPARISON BETWEEN DAYLIGHT FACTOR AND STANDARD DAYLIGHT FACTOR FOR GROUND FLOOR OF SEVEN MARLA HOUSE

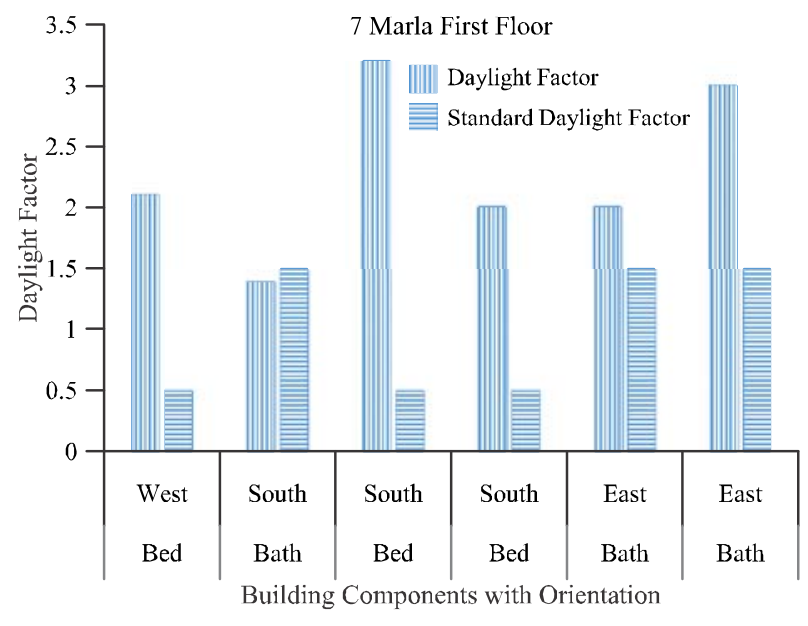

FIG. 7. COMPARISON BETWEEN DAYLIGHT FACTOR AND STANDARD DAYLIGHT FACTOR FOR FIRST FLOOR OF SEVEN MARLA HOUSE

daylight factor and daylight intensity which is not compatible to CIBSE standards.

(ii) Both 5 and 7 marla houses are energy deficient. The higher illuminance level and daylight factor in building components will contribute more cooling cost during summer.

(iii) The daylight intensity and daylight factor can be reduced to meet the standards of CIBSE by either reducing the opening size or by reducing the glazing area. 
(iv) The daylight intensity and daylight factor in most building components oriented in east-west direction is higher than building components oriented in north south direction. Keeping it in mind, the main living components (Bed rooms and lounge) of 5 marla house are oriented in east-west direction. Therefore, the daylight intensity and daylight factor is much higher and ultimately will result more energy consumption for cooling.

\section{RECOMMENDATIONS}

Since the energy resources are depleting day-by-day, therefore, it is need of the hour to make a thorough research in this area. The present study does not fulfill detailed aspects of day lighting in buildings, however, further aspects can be investigated as:

(i) Entrance of sufficient daylight into building can reduce the cost of energy, thus, proper design in this regard makes the building energy efficient. A further study can be performed on relationship between daylight entrance and corresponding energy saving.

(ii) Entrance of daylight certainly depends upon the orientation of different components of buildings. A thorough study can be made in this regard.

(iii) This study will help architects or building designers to locate or orientate major building units like bedrooms and living halls in a position where there would be more penetration of daylight, which results in minimizing the electricity consumption.

(iv) As we know insufficient daylight into building can seriously affect the health and working efficiency of working personnel. This study can be further done particularly in libraries, classrooms, and offices.

(v) Existence of moisture and insufficient daylight is a favorable place for breeding of anaerobic bacteria which creates odor. Therefore, the study in this regard would be very valuable.

\section{ACKNOWLEDGEMENTS}

Authors would like to show their immense gratitude to anonymous referees for sharing their valuable views and suggestions during the period of this research. Their comments and insights truly led us to increase the quality of this paper. Authors are also thankful to the Department of Archtitectural Engineering \& Design, University of Engineering \& Technology, Lahore, for providing instruments, and Cantonment Cottages Multan, Pakistan, for prodving the platform to carry out this research.

\section{REFERENCES}

[1]

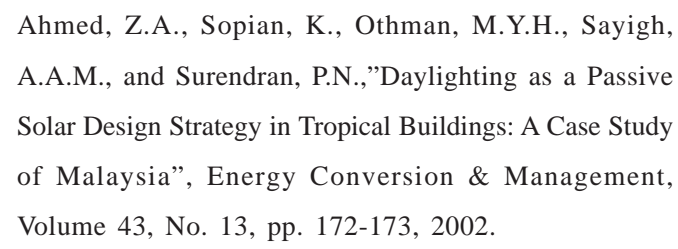
A.A.M., and Surendran, P.N.,”Daylighting as a Passive Solar Design Strategy in Tropical Buildings: A Case Study of Malaysia”, Energy Conversion \& Management, Volume 43, No. 13, pp. 172-173, 2002.

[2] Arif, S., Khan, A., and Alamgir, K., "Modeling the Temperature Effect of Orientations in Residential Buildings, Mehran University Research Journal of Engineering \& Technology, Volume 31, No. 3, Jamshoro, Pakistan, July, 2012. Buildings' Thermal Loads against Building Orientations for Sustainable Housing in Pakistan”, Mehran University Journal of Engineering \& Technology, Volume 31, No.3, Jamshoro, Pakistan, July, 2012. 
[4] "Daylight in Buildings”, Energy Conservation in Buildings and Community System \& Solar Heating and Cooling Program”, International Energy Agency, ECBCS Annex 29/SHC Task-21, 2010.

[5]

Capeluto, I.G., "The Influence of the Urban Environment on the Availability of Daylighting in Office Building in Israel”, Building and Environment, Volume 38, No. 5, pp. 745-752, 2003.

[6] Youssef, W.F., "Natural Light and Libraries", Ph.D. Dissertation, University of Pennsylvania, pp. 14, USA, 1979
[7] Rea, M., "Light-Much More than a Vision, Light and Human Health”, EPRI/LRO $5^{\text {th }}$ International Lighting Research Symposium, Palo Alto, CA, The Lighting Research Office of the Electric Power Research Institute, pp. 15, 2002.

[8] Lim, G., Hirning, M.B., Keumala, N., and Ghafar, N.A., "Daylight Performance and Users' Visual Appraisal for Green Building Offices in Malaysia”, Energy and Buildings, 141,175-185, 2017

[9] “CIBSE Code for Lighting Part-2", Chartered Institution of Building Engineers, London, UK, 2002. 